\title{
Characteristics of Fish Protein Hydrolysate from Yellowstripe Scad (Selaroides leptolepis) Produced by a Local Microbial Protease
}

\author{
Yusro Nuri Fawzya ${ }^{1 *}$, Safira M. Nursatya ${ }^{2}$, Rini Susilowati ${ }^{1}$, Ekowati Chasanah ${ }^{1}$ \\ ${ }^{1}$ Research Centre for Marine and Fisheries Product Processing and Biotechnology \\ Jalan K.S.Tubun, Petamburan VI, Jakarta \\ ${ }^{2}$ Universitas Jenderal Soedirman, Purwokerto
}

\begin{abstract}
Fish protein hydrolysate (FPH) containing small protein or peptides and amino acids has a great attention related to the provision of high protein foods to overcome the problem of malnutrition. This research was purposed to prepare FPH from yellowstripe scad (Selaroides leptolepis) by using a local microbial protease from Bacillus subtilis BII-1. Hydrolysis process was done in a laboratory scale $\left(500 \mathrm{~g}\right.$ minced fish) at $55^{\circ} \mathrm{C}$ for $6 \mathrm{~h}$. The liquid hydrolysate was then spray dried using whey protein and maltodextrin at a concentration of 20 and $30 \%$ for each filler. The treatment of whey protein powder produced FPHs with higher protein content $(31.71-33.97 \% \mathrm{db})$ and slightly yellowish in color compared to maltodextrin $(11.88-16.66 \% \mathrm{db})$. Their foaming capacity and stability were $20-100 \%$ and $15 \%$ in 5-10 min, respectively. However, FPHs prepared with maltodextrin had no foaming capacity. The hydrolysates from both treatments had low water and oil absorption with the value less than $3 \mathrm{~mL} / \mathrm{g}$ hydrolysate. A trial on scaling up production using $30 \mathrm{~kg}$ fish, showed that optimization or adjustment should be carried out due to the high amount and high protein content of the residual products.
\end{abstract}

\section{Introduction}

The supply of nutritious food, particularly rich in protein is required by most of the world, including Indonesia, which currently deals with the problem of stunting. Children suffering from stunting reached $37.2 \%$ in 2013, higher than that at the year of 2010 (36.8\%) [1]. Many factors involved in this problem including the low income, poor of sanitation and hygiene, lack of education, and provision of nutritious food.

Fish as source of high quality animal protein is available abundantly at affordable prices. However, it has not proportionately distributed in its role to achieve nutritional adequacy for Indonesian people. In addition, fish are very perishable and vary in their chemical composition which present specific problems in their processing.

\footnotetext{
${ }^{*}$ Corresponding Author: nurifawzya@gmail.com
} 
Fish protein hydrolysate (FPH) is a hydrolyzed fish protein which is more easily digested and absorbed than native protein due to its simple form as peptides and amino acids. The product can be processed by the enzymatic as well as chemical methods. By hydrolyzing, the fish protein is broken down into peptides and amino acids with smaller molecular weight. Fish protein hydrolysate has a wide application in accordance with its functional properties including as protein supplement and fortificant, stabilizer, flavor enhancer, and milk replacers [2]. Many researches on FPHs production have been published which mostly done by enzymatic method. Commonly, the commercial enzymes were used, including papain and alcalase. Enzymatic FPHs production was derived from various fish or fish by-products, such as sardines (Sardinella lemuru) [3], 'lele dumbo' (Clarias gariepinus) [4], fish by-products [5], Clarias batrachus, a freshwater catfish [6], and tilapia fish waste mince [7]. Local proteases used in FPHs processing were found in a limited number of papers, such as biduri protease [8], local papain [9] [10] and microbial protease produced from Bacillus sp. isolated from marine environment [11] [12].

Previous study on preparation of protein hydrolysate from yellow stripe scad using a local Bacillus subtilis BII-1 protease showed that the optimum hydrolysis time was $6 \mathrm{~h}$. The total activity of enzyme used was $500 \mathrm{U}$ for $75 \mathrm{~mL}$ fish slurry [11]. The resulting liquid FPH needs to be converted into a powder form through drying process, to extend the shelf life and make easy in distribution. Freeze drying is considered to be the best method because this process allows us to maintain the high protein of FPH. However, this method is quite expensive to apply on a larger scale. Other drying method used to prepare powdered FPH at an industrial scale is spray drying [13], which is lower in cost, but lower in protein content due to the addition of filler before spray dried. Protein hydrolysate from yellowstripes cads contained protein in the range of $39.94-51.76 \%$ when it was dried by ultrasonic spray drier; and 50.90 $-60.23 \%$ when was dried by a freeze drier [14]. Whereas, the protein content of peptones powder from Lutjanus sp. spray dried with maltodextrin as the filler, was 20-38\% [15]. Maltodextrin and arabic gum were also used as the carrier agent in pink perch protein hydrolysate for reducing its bitter taste and to characterize the protein hydrolysates [16]. Maltodextrin is a polysaccharide which is the most frequently used as encapsulant in spray drying of food due to its effectivity in protecting food from oxidation, besides its other advantages properties such as high solubility and rapid dispersion [17, 18]. In this research we used maltodextrin, compared to whey protein powder in spray-drying FPH from yellowstripe scad, and evaluate their effect on the protein content and properties of FPH powder produced.

Production of FPH in laboratory scale is the basis of production process before scaling up process at pilot plant and industrial scale. Pilot plant scale production is intended to get products which are identical (if possible) on a larger scale than the predetermined production scale. In this work, an initial trial of scaling up FPH production was studied to obtain mass balance information and evaluate the changes or differences of the FPH quality during scaling up.

\section{Materials and methods}

\subsection{Materials}

Fish used for a laboratory scale study was fresh Yellostripe scad (Selaroides leptolepis) obtained from Muara Angke, Jakarta with the average size of $14.36 \pm 0.77 \mathrm{~cm}$ in length, 4.15 $\pm 0.16 \mathrm{~cm}$ in width and $34.18 \pm 4.14 \mathrm{~g}$ in weight. The fish had moisture content of $81.28 \pm 0.61$ $\%$, ash content of $0.49 \pm 0.02 \%$, protein content of $13.83 \pm 2.35 \%$ and fat content of $0.75 \%$. Meanwhile, frozen fish was used for the scaling up trial. The fish was bought from the auction 
place (TPI) in Tegal, Central Java, packed in a Styrofoam box to keep cold, and brought to the laboratory in Jakarta. The fish was then eviscerated and filleted in a cold chain system by using pieces of ice, and kept in a cold storage until processed into Fish Protein Hydrolysate (FPH). Local microbial protease was prepared from Bacillus subtilis BII-1, a collection isolate of RCMFPB laboratory isolated from hot spring at Banyuwedang, Bali [19].

\subsection{Preparation of enzyme}

Protease enzyme was produced from Bacillus subtilis BII-1 following the method of Fawzya's trial [11]. Fresh isolate was firstly inoculated in Minimal Synthetic Medium (MSM) containing $0.1 \% \mathrm{~K}_{2} \mathrm{HPO}_{4} ; 0.1 \% \mathrm{NaCl} ; 0.7 \%\left(\mathrm{NH}_{4}\right)_{2} \mathrm{SO}_{4} ; 0.05 \%$ yeast extract; $0.01 \%$ $\mathrm{MgSO}_{4} ; 0.6 \%$ technical grade skim milk, then incubated at $37^{\circ} \mathrm{C} 125 \mathrm{rpm}$ for $18 \mathrm{~h}$. Crude enzyme was separated as supernatant from centrifugation the culture at $8,000 \mathrm{rpm}, 4^{\circ} \mathrm{C}$ for $20 \mathrm{~min}$. The enzyme activity was assayed based on Zilda's method [19].

\subsection{Preparation of fish protein hydrolysate (in a laboratory scale)}

Fish protein hidrolysate was prepared according to Fawzya et al. [11]. Fish fillet was chopped and blended with water (ratio 1:2 w/v). Approximately $1.5 \mathrm{~L}$ of fish slurry from 500 g minced fish with $1 \mathrm{~L}$ of water was heated until the temperature of $55^{\circ} \mathrm{C}$ achieved, and then added with $33 \mathrm{~mL}$ of $300 \mathrm{U} / \mathrm{mL}$ Bacillus protease. The mixture was stirred for $6 \mathrm{~h}$ at $55^{\circ} \mathrm{C}$ for hydrolysis process. After $6 \mathrm{~h}$ hydrolysis, the reaction was stopped by increasing the temperature to $90^{\circ} \mathrm{C}$, kept for $20 \mathrm{~min}$. The hydrolysate was separated by centrifugation $(8000$ $\mathrm{x} \mathrm{g}$ ) for 10 minutes. Hydrolysate powder was prepared by spray drying using 2 types of fillers, i.e. a commercial whey protein powder (coded as PC) and maltodextrin (coded as MD) with the concentration of each filler was 20 and $30 \%$.

\subsection{Preparation of fish protein hydrolysate in a larger scale $( \pm 30 \mathrm{~kg}$ fish)}

Similar with the preparation of FPH in a laboratory scale (500 $\mathrm{g}$ minced fish or approx. 1.0 $\mathrm{kg}$ fish), the equipment used was slightly different with the lab-scale experiment. Hydrolysis process was done in a stainless steel tank equipped with temperature control and an agitation with a capacity of $100 \mathrm{~kg}$ of fish slurry. Whereas, hydrolysate was separated by using gradual filtration, starting from filter with size of 300 mesh, 600 mesh, microfiltration $(5 \mu \mathrm{m})$ and ultrafiltration $(0.1 \mu \mathrm{m})$. The liquid hydrolysate was partially sampled for freeze drying and the rest was spray dried which was preceded by addition of maltodextrin and whey protein powder with the concentration of $20 \%$ for each filler and homogenization at $16,000 \mathrm{rpm}$ for $10 \mathrm{~min}$. Spray drying was done at inlet temperature of $160^{\circ} \mathrm{C}$, outlet temperature of $90^{\circ} \mathrm{C}$ and aspirator of $90 \%$. Mass balance at each processing step was observed as well as moisture and protein content.

\subsection{Analysis}

The resulting FPHs were analyzed for their nutritional content and physical properties. Proximate composition were determined according to SNI. Moisture content was determined by SNI 2354.2:2015 [20], ash content by SNI2354.1:2010 [21], protein by modification of SNI 01-2354.4-2006, using Kjeltec [22], fat content by SNI 2354-3-2006 [23]. The analysis of physical properties of FPHs included color by using the Hunterlab colorimeter (ColorFlex EZ) with the parameters of $\mathrm{L}^{*}$ from black (0) to white (100), a* from green (1) to red (+), and $b^{*}$ from blue (-) to yellow (+) [24], foam capacity and stability [25], water 
absorption [26], and oil absorption [27 with modification]. Mass balance was observed in the preparation of FPH at the pilot scale. Research was done in 2 replicates, except scaling up production which was done with no replication. The data were presented as an average values, and were analyzed by descriptive method.

\section{Results and discussion}

\subsection{Chemical composition}

Yellowstripe scad (Selaroides leptolepis) used in this study was categorized as low fat fish because the fat was less than 5\% [28, 29]. When processing into FPHs powder, their protein content were affected by filler used. Whey protein powder coded as PC produced higher protein content of FPH compared to maltodextrin. It is due to the protein content of filler, which PC has protein content much higher than maltodextrin (20.36 vs $0.42 \%)$. Before drying process, the liquid hydrolysate contained of $90.85 \%(\mathrm{db})$ protein, meanwhile the protein content of FPHs powder were at the range of $11.88 \pm 0.08$ to $33.97 \%$ (db) (Figure 1). This result was lower compared to yellowstripe scad protein hydrolysate reported previously [14]. They found that the hydrolysate powder produced by hydrolysis of yellowstripe scad using alcalase and ultrasonic spray dried contained protein varied from 40.06 to $51.76 \%$, meanwhile those freeze dried had the protein content ranged from 52.86 to $60.23 \%$. Many studies reported that fish protein hydrolysates contained much higher protein content, ranged from about 60 to $90 \%$ [30]. This is mainly because the FPHs were commonly produced in liquid form and the presented data are in \% dry base. Besides, they were prepared in a powder form by freeze drying method with no addition of other substances, for example liquid FPH from milkfish (Chanos chanos Forsk) [31] and freeze dried protein hydrolysate from Pacific whiting muscle [32].

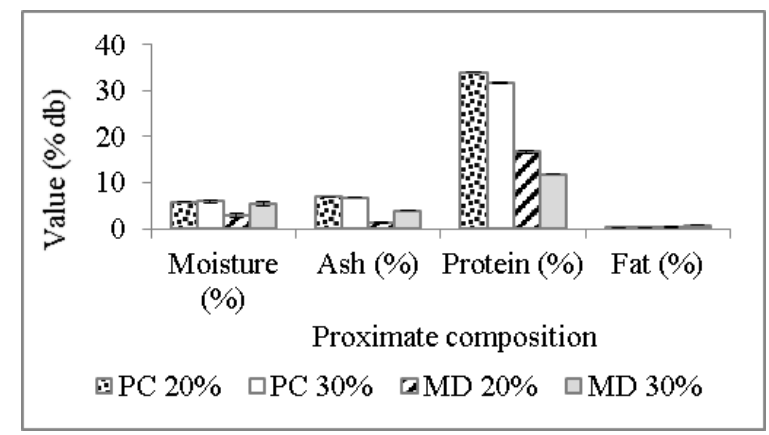

Note : PC : a commercial whey protein powder MD : maltodextrin

Fig. 1. Proximate composition of fish protein hydrolysate powder from yellowstripe scad

The research produced a comparable result with FPH powder from silver catfish frame which spray dried using 5\% maltodextrin and consisted of protein in the range of 32.9-35.6\% [34]. Meanwhile, spray dried black Tilapia hydrolysates with $10 \%$ maltodextrin contained $37.7 \%$ [35]. A high protein hydrolysate powder which was dried using a spray drier was reported on hydrolyzed red meat of Euthynnus affinis [30]. The protein content of FPH was much higher than our result ( $\sim 90 \%$ vs $\sim 30 \%)$. It might be due to the less ratio of fish to water $(1: 1)$ used in the process [30] resulted in more concentrated liquid FPH that no need addition 
of filler to spray dry it. The addition of filler in our research was aimed at reducing the stickiness and wall deposition in spray-drying [35].

\subsection{Physical properties}

\subsubsection{Color}

Color is one of the factors affecting in overall product's acceptance. It may be influenced by raw materials used, as well as hydrolysis and drying condition. The color measurement of the FPH showed that FPH produced by using PC filler exhibited a light yellowish color compared to the use of MD filler which had the higher value of $\mathrm{L}^{*}$ and lower value of $\mathrm{b}^{*}$ (Table 1). It might be due to the higher protein content of FPH-PC that was more sensitive to heat during the drying process for Maillard reaction.

Table 1. Hunter lab color parameter values of yellowstripe scad protein hydrolysate (FPH)

\begin{tabular}{cccc}
\hline Treatments & L $^{*}$ & $\mathbf{a}^{*}$ & $\mathbf{b}^{*}$ \\
\hline PC 20 & 94.97 & -0.41 & 13.09 \\
\hline PC 30 & 95.49 & -0.82 & 11.36 \\
\hline MD 20 & 96.70 & -0.18 & 5.70 \\
\hline MD 30 & 96.27 & -0.33 & 5.26 \\
\hline
\end{tabular}

\subsubsection{Foaming properties}

Foaming capacity and stability of FPHs from yellowstripe scads were presented in Figure 2. It is shown that treatment MD did not produce foam at all, so there is no stability data either. Meanwhile, foam capacity from treatment PC increased in line with the increased of FPH concentration. This FPH with the concentration of $2 \%$ had the foam ability of $40-100 \%$. Similar result was shown by protein hydrolysate from fish by product. At the concentration of $3 \%$, the foam expansion of FPH reached $60-80 \%$, meanwhile $0.1 \%$ FPH had foam capacity of 40 to $50 \%$ [36]. On the contrary, higher concentration of filler decrease foam capacity of FPH but increase their stability which can be seen from PC 30 vs PC 20. Compared to other FPH with higher protein content, such as freeze-dried FPH (protein of 70-80\%) the foam stability of FPH produced by this research was much lower (remained 15\% in 5-10 min vs remained $15 \%$ in $60 \mathrm{~min}$ ). Another factor that may affect the foaming properties is degree of hydrolysis. Foam capacity and stability generally increase by the increase in degree of hydrolysis (DH), however excessive hydrolysis can have contrary effects on the foaming properties. Protein hydrolysis at the initial process (DH up to 12-15\%) increased the lower molecular weight of protein, improve the solubility and hydrophobicity as well as the molecular flexibility, which then forming a more stable foam. Further hydrolysis with DH more than $15 \%$ led small peptides to increase the incorporation of air into the dispersion than larger peptides, thereby reducing foam capacity and stability [37, 38]. 


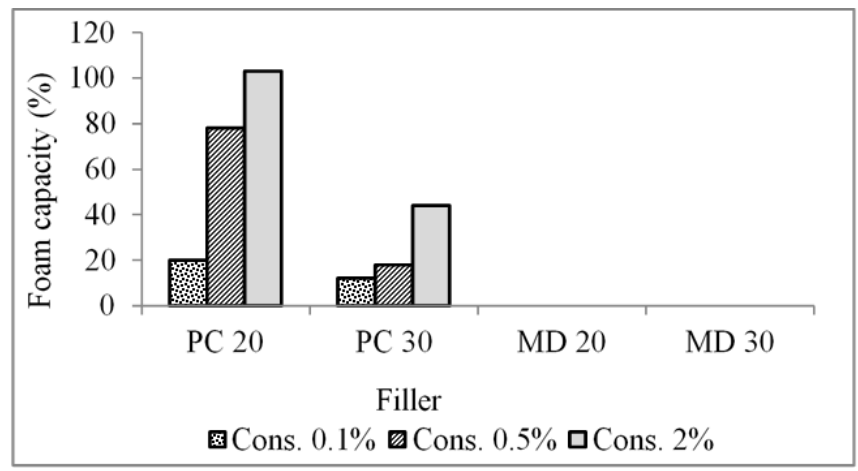

A

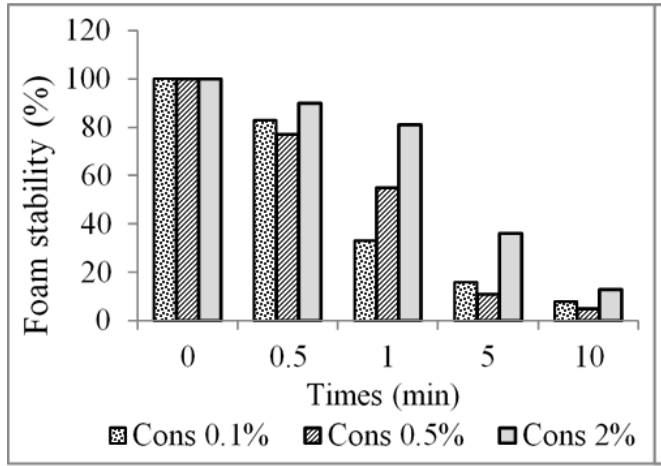

B

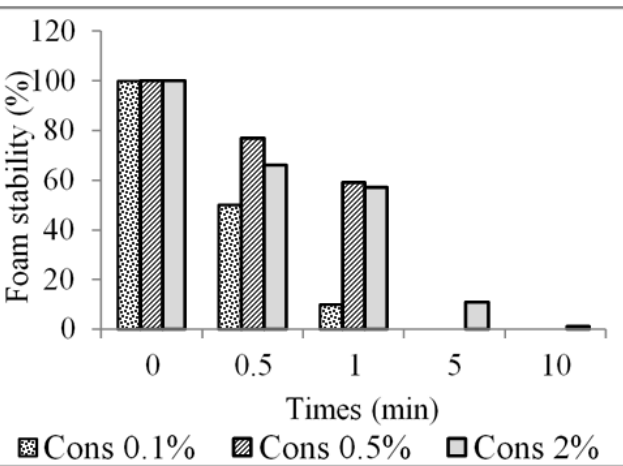

C

Fig. 2. Foaming properties of FPH from yellowstripe scad : foam capacity (A), foam stability of FPH using 20\% PC (B) and foam stability of FPH using 30\% PC (C)

\subsubsection{Other physical properties}

Other physical properties observed were water and oil absorption (Table 2). It is shown that oil absorption of the FPH from yellowstripe scad was relatively low, ranged from 1.3 to $2.1 \mathrm{~mL} / \mathrm{g}$. This oil absorption capacity was similar with that from rainbow trout viscera protein hydrolysate $(2.8-3.1 \mathrm{~mL} / \mathrm{g}$ hydrolysate) [24]. The oil absorption is affected by size and nature of peptides [39]. Hydrophobic peptides with large molecule size have good ability in oil absorption. They found that oil absorption of protein hydrolysate from fresh water mussel Lamellidens marginalis varied from 12-35 mL/g FPH. Similar results were obtained in water absorption, where FPH from yellowstripe scads showed low absorption of water $(0.1$ $-0.3 \mathrm{~mL} / \mathrm{g}$ ). Previous report found that protein hydrolysate from rainbow trout viscera had water holding capacity $5.1 \mathrm{~mL} / \mathrm{g}$ hydrolysate [24]. 
Table 2. Oil and water absorption of FPH from yellowstripe scad

\begin{tabular}{|l|c|c|c|c|}
\hline Physical properties & PC 20 & PC 30 & MD 20 & MD 30 \\
\hline Oil absorption $(\mathrm{mL} / \mathrm{g})$ & 1.9 & 2.1 & 2.1 & 1.3 \\
\hline Water absorption $(\mathrm{mL} / \mathrm{g})$ & 0.3 & 0.1 & 0.3 & 0.23 \\
\hline
\end{tabular}

\subsection{A trial on scaling up production of FPH}

In order to scaling up production of FPH, a trial has been conducted by using a stainless steel hydrolysis tank with the capacity of $100 \mathrm{~L}$ slurry and an ultrafiltration membrane to separate the hydrolysate. Filtration using a 300 and 600 mesh filter bag initiated the separation step of hydrolysate, followed by filtration using micro and ultrafiltration. The first filtering step produced the largest amount of by-product, reached $7.5 \%$ composed of $1.3 \%$ frame and scales, and $6.2 \%$ meat fibers. Whereas, micro and ultrafiltration leaving soft fish pulp or paste about $2.5 \%$ (Table 3 ). The abundance in amount of meat fibers residue was found which may be caused by the non-optimal hydrolysis process of fish protein at upscale condition. The upscale process requires adjustment or optimization to reduce the by-products, such as prolong the hydrolysis time, reducing the ratio of fish meat: water or increasing the concentration of enzymes.

Table 3. Mass balance of FPH processing from yellowstripe scad at production scale of $30 \mathrm{~kg}$ fish

\begin{tabular}{|l|c|c|}
\hline Step & Product & $\begin{array}{c}\text { Yield (\% based on } 30 \mathrm{~kg} \\
\text { fish) }\end{array}$ \\
\hline Fish & Fillet $15 \mathrm{~kg}$ & 50 \\
\hline Minced meat & $13.5 \mathrm{~kg}$ & 45 \\
\hline Water & $27 \mathrm{~L}$ & \\
\hline Enzyme (300 U/mL) & $900 \mathrm{~mL}$ & \\
\hline Liquid FPH & $37 \mathrm{~L}$ & 1.3 \\
\hline Residue 300 mesh & $400 \mathrm{~g}$ & 6.2 \\
\hline Residue 600 mesh & $1.850 \mathrm{~g}$ & 1.5 \\
\hline Residue microfiltration & $450 \mathrm{~g}$ & 1.0 \\
\hline Residue ultrafiltration & $300 \mathrm{~g}$ & \\
\hline Liquid FPH (ultrafiltration) & $31.5 \mathrm{~L}$ & 19.7 \\
\hline Filler (20\%) & $6.3 \mathrm{~kg}$ & 10 \\
\hline $\begin{array}{l}\text { HPI padat (spray dried } \\
\text { filtration) }\end{array}$ & $5.9 \mathrm{~kg}$ & \\
\hline Total residues & $3.000 \mathrm{~g}$ & \\
\hline
\end{tabular}

Observation on moisture and protein content of products from each step are presented on Table 4. Both liquid and freeze dried FPHs contained high protein reached above $90 \%(\mathrm{db})$, meanwhile the protein of spray dried FPHs were much lower, ranged from 14.09 to $32.44 \%$ (db). This was because of the addition of filler up to $20 \%$. Maltodextrin is a polysaccharide produced from starch that is used as a food additive. Based on the nature, liquid hydrolysate produced industrially concentrated from 25 to $50-60 \%$ solid before drying [40]. Concentration of the liquid FPH reduces the amount of filler used, and increase the protein content of FPH powder. High protein by-products of FPH processing were also observed on dried residue of 600 mesh filtration, with the protein content of $80.83 \%$ (db) similar with the centrifugation's residue of $80.70 \%(\mathrm{db})$. This remaining protein content in these residues may 
be used as raw material to obtain higher value-added products. The residue of sardinella protein hydrolysate preparation had high content of glutamic acid which potential to be used as flavor enhancer [12].

Table 4. Moisture and protein content of each step products of FPH processing

\begin{tabular}{|c|c|c|c|c|}
\hline \multirow[b]{2}{*}{ Sample } & \multicolumn{2}{|c|}{ Lab scale } & \multicolumn{2}{|c|}{ Upscale } \\
\hline & $\begin{array}{c}\text { Moisture } \\
(\% \text { wb })\end{array}$ & $\begin{array}{l}\text { Protein }(\% \\
\text { db) }\end{array}$ & $\begin{array}{c}\text { Moisture } \\
(\% \text { wb })\end{array}$ & $\begin{array}{l}\text { Protein } \\
(\% \text { db })\end{array}$ \\
\hline Liquid FPH & 97.27 & 90.85 & 93.33 & 91.45 \\
\hline Freeze dried FPH & - & - & 8.56 & 92.47 \\
\hline Spray dried FPH MD 20\% & 2.8 & 16.66 & 2.87 & 14.09 \\
\hline Spray dried FPH PC $20 \%$ & 5.76 & 33.97 & 3.49 & 32.44 \\
\hline Centrifugation's residue & 74.25 & 80.70 & - & - \\
\hline $\begin{array}{l}\text { Dried Residue } 300 \text { mesh } \\
\text { (vacuum oven) }\end{array}$ & - & - & 4.57 & 76.40 \\
\hline $\begin{array}{l}\text { Dried Residue } 600 \text { mesh } \\
\text { (vacuum oven) }\end{array}$ & - & - & 5.06 & 80.83 \\
\hline
\end{tabular}

It was also investigated that the resulting FPH had the whiteness value of $87.3 \%$ and did not have any bitter taste. Small hydrophobic peptides were the main contributor to the bitter taste [41]. In addition, the type of proteases had the most significant impact on the properties of FPH. The Bacillus subtilis protease used in this research has similar properties to alcalase, including its optimum temperature and $\mathrm{pH}$ [42]. Alcalase is widely used for FPH preparation because it produced FPH with relatively high degree of hydrolysis in relative short time [2].

\section{Conslucion}

Hydrolysis of yellowstripe scads protein by using a local Bacillus subtilis BII-1 protease produced protein hydrolysate which had no bitterness. Spray drying using whey protein powder produced FPHs with higher protein content than that using maltodextrin. The use of whey protein powder as filler gave better quality of hydrolysate powder. However, process improvement needs to be done in order to increase the protein content or other properties of hydrolysates, and minimize the residual amount. 


\section{Aknowledgement}

We thank Dr. Dewi S. Zilda for her permission to use the bacterial isolate for enzyme production; and we acknowledge that the first author is the main contributor of this research.

\section{References}

1. Pusat Data dan Informasi Kementerian Kesehatan RI. Info datin ISSN2442-7659 (2016). http://www.depkes.go.id/resources/download/pusdatin/infodatin/situasi-balita-pendek2016.pdf. Accessed by June 2019

2. H.G. Kristinsson and B.A. Rasco, Critical Rev in Food Sci and Nut , 40 (1): $43-81$ (2000)

3. W. Handayani, A.A.I. Ratnadewi, and A.B Santoso. J. Teknol. Proses 6(1):1-9 (2007)

4. E. Salamah, T. Nurhayati, and I.R. Widadi. 2012. J. Pengol. Hasil Perik Indonesia, 15 (1) : $10-16$ (2012)

5. M. Muzaifa, N. Safriani, and F. Zakaria, Int. J. Bioflux Soc. Aquaculture, Aquarium, Conserv. \& Legislation 5 36-39 (2012).

6. M.S. Seniman, S.M. Yusop, and A.S. Babji. AIP Conference Proceedings 1614 : 323 328 (2014)

7. A. Srikanya, K. Dhanapal, K. Sravani, Madhavi and G.P. Kumar, Int. J. Curr. Microbiol. App. Sci 6(12): 3220-3229 (2017)

8. Y. Witono. Agritek, 15 (5): 988-992 (2007)

9. F. Ariyani, M. Saleh, Tazwir and N. Hak, J. Indonesian Fish. Res. 9, 11-19 (2003)

10. S. Annisa, YS. Darmanto, and U. Amalia, Saintek Perikanan 13(1) : 24-30 (2017)

11. Y.N. Fawzya, P. Martosuyono, and D.S. Zilda, Pros. Semnas Kelautan dan Perikanan 89-96 (2017).

12. E. Chasanah, R. Susilowati, M. P. Martosuyono, D.S. Zilda, and Y.N. Fawzya. IOP Conf. Series: Earth and Environmental Science 278 (2019)

13. L.D. De Paris, J.C.A. Haab, C. Sary, D.M. Bernardi, W.R. Boscolo, and A. Signor, Acta Scientiarum. Technology (38) 1: 89-97 (2016)

14. Hau, E. H., Mohd Zin, Z., Zuraidah, N., Shaharudin, N. A. and Zainol, M. K., Int. Food Res. J. 25(6): 2553-2559 (2018)

15. R. Ningsih, Sudarno and Agustono. Agrointek 12(1):55-60 (2018).

16. L.N. Murthy, G.G. Phadke, C.O. Mohan, M.V. Chandra, J. Annamalai, S. Visnuvinayagam, P. Unnikrishnan, and C.N. Ravishankar. Journal of Aquatic Food Product Technology, 26:8, 913-928 (2017)

17. C.A. Batista, D. Constenla, M.V. Ramirez-Rigo, J. Pina. Journal of Powder Technology 286:193-201 (2015)

18. E. Srihari, F.S. Lingganingrum, R. Hervita, S. Wijaya. Prosiding Seminar Rekayasa Kimia dan Proses: 1411-4216 (2010)

19. D.S. Zilda, E. Harmayani, J. Widada, W. Asmara, H. E. Irianto, G. Patantis, dan Y. N. Fawzya, Squalen Bull. of Marine and Fish Postharvest and Biotech. 7 (3): 105-114 (2012)

20. Badan Standardisasi Nasional. SNI 2354-2-2015 (2015)

21. Badan Standardisasi Nasional. SNI 2354-1-2010 (2010)

22. Badan Standardisasi Nasional . SNI 01-2354.4-2006 (2006)

23. Badan Standardisasi Nasional. SNI 2354.3-2006 (2006)

24. A.Taheri, S.A.A. Anvar, H. Ahari, and V. Fogliano. Iranian J. of Fish. Sci. 12(1) 154169 (2013)

25. F. Shahidi, XQ Han, J. Synowiecki, Food Chemistry 53(3):285-293 (1995) 
26. A. Apriantono, D. Fardiaz, N.L. Puspitasari, S. Yasni, and S. Budiyanto. Petunjuk Laboratorium Analisa Pangan. Pusat Antar Universitas Pangan dan Gizi. IPB (1989)

27. C.S. Lin and J.F. Zayas, J. of Food Sci., 52, 1308-1311 (1987)

28. M.E. Stansby, Properties of Fish Oils and their Application to Handling of Fish and to Nutritional and Industrial Use. In: Chemistry and Biochemistryof Marine Food Products, R.E. Martin, G.J. Flick, C.E. Hebard and D.R. Ward, (Eds.). Avi Publishing Co., Westport, CT., pp: 75-92 (1982).

29. R.G. Ackman, 1989. Prog. Food Nutr. Sci., 13: 161-289 (1989)

30. U. Parvathy, K.M. Nizam, A.A. Zynudheen, G. Ninan, S.K. Panda and C.N. Ravishankar, J. of Sci. \& Industrial Res. 77:111-119 (2018)

31. I. Wijayanti, Romadhon, and L. Rianingsih. J. Saintek Perikanan 11(2): 129-133 (2016)

32. R. Pacheco-Aguilar, M.A. Mazorra-Manzano, and J.C Ramirez-Suarez, Food Chemistry 109: $782-789$ (2008)

33. M.A.Amiza, Y.W. Ow, and A.L. Faazaz, Int. Food Res. J. 20(3): 1255-1262 (2013)

34. J.B. Abdul-Hamid, and G.H. Bee, Food Chemistry 78: 69-74 (2002)

35. V. Truong, B.R. Bhandari and T. Howes, J. of Food Eng. 71: 55-65 (2005)

36. M. Muzaifa, N. Safriani, and F. Zakaria, Aquaculture, Aquarium Conservation \& Legislation 5(1): 36-39 (2012).

37. Zhi-jie Bao, Y. Zhao, Xiao-ying Wang and Yu-Jie Chi. 2017. J Food Sci Technol (March 2017) 54(3):669-678

38. M.A. Amiza, D. Khuzma, P.S. Liew, M. Salma Malihah and N.M. Sarbon. Food Research 3 (6) : $664-677$. (2019)

39. Haldar, M. Das, R. Chatterjee, T.K. Dey, P. Dhar, and J. Chakrabarti. Indian J. of Biochem. \& Biophys. 55:105-113 (2018)

40. V. K. Pasupuleti and S. Braun. In: V.K. Pasupuleti and A.L. Demain (eds.) Protein hydrolysates in Biotechnology,. (C) Springer Science+Business Media B.V. (2010)

41. I.W.Y. Cheung. Thesis. The Faculty of Graduate Studies (Food Science). The University of British Columbia. 2007.

42. D.S. Zilda, Y.N. Fawzya, and A.R. Uria, Squalen Bull. of Mar. and Fish. Postharvest and Biotech. 13 (3):101-108 (2018) 